\title{
TRAVEL BEHAVIOUR OF ONLINE SHOPPERS IN SWEDEN
}

\author{
Lena Winslott Hiselius ${ }^{1}$, Lena Smidfelt Rosqvist ${ }^{2}$, Emeli Adell ${ }^{2}$ \\ ${ }^{1}$ Lund University - Department of Technology and Society \\ Box 118, SE-22100 Lund, Sweden \\ Phone: +46 46 2229748,E-mail: lena.hiselius@tft.lth.se \\ ${ }^{2}$ Trivector Traffic \\ Aldermansgatan 13, SE-222764 Lund, Sweden \\ E-mail:lena.rosqvist@trivector.se; emeli.adell@trivector.se
}

\begin{abstract}
Online shopping opportunities are transforming travel behaviour for shopping and could potentially reduce the overall travel demand. Despite numerous studies on online shopping, only a few have taken an approach that includes trips for all travel purposes. Based on a web-survey, this paper provides results on travel behaviour for physical shopping for frequent, regular, and infrequent online shoppers in Sweden. The results indicate that frequent online shoppers make as many car trips (for both shopping and other errands) as others. Also, frequent online shoppers in total make as many trips to a physical store as infrequent online shoppers - although by more sustainable modes of transport - and that the time saved from online shopping is spent on both additional shopping trips and trips for other errands. The conclusion is that online shopping might facilitate changing travel behaviour but does not in itself represent a good stand-alone measure for reducing vehicle mileage.
\end{abstract}

Keywords: Online shopping, travel behaviour, modal split

\section{Introduction}

The market share of online shopping has been steadily growing in recent years (Fredriksson 2013), and this is to some extent affecting traditional commerce. The phenomenon of shopping through nonlocal channels is not new, and mail order shopping and travelling salesmen are long-standing examples of this. The Internet, however, has opened up new markets and offers a previously unknown level of accessibility for businesses as well as for consumers.

In theory, online shopping has the potential to lead to dramatic decreases in needs for personal transportation. Personal shopping trips in Sweden account for approximately one of every fifth passenger trip and one of every ten passenger kilometres, and these rates are similar in other European countries (Trivector 2011). Most shopping trips are made by car, and if online shopping can reduce the number and length of those car trips it would provide an interesting way for the transport sector to reduce carbon dioxide emissions and other negative effects of car use.

Online shopping can, in principle, result in three different behavioural impacts. The first possibility is that online shopping can act as a substitute, which means that every aspect of shopping is carried out online and which reduces the number of actual shopping trips (Salomon 1986). However, one must also recognize that shopping can have a recreational function and can serve as an opportunity to meet people and that this could counteract the substitution effect of online shopping (Mokhtarian 2004). The second possibility is that online shopping can act in one of two complementarity fashions that are based on two distinct types of interactions. The first complementarity interaction is enhancement, which implies that online shopping generates additional shopping trips that would not have occurred without the online shopping. The second complementarity interaction is operational efficiency, which refers to situations where online shopping improves traditional shopping to make it more efficient or satisfactory (Salomon 1986; Mokhtarian 1990, 2002). For example, consumers can use the online option to search for product information, which might reduce the time or trips needed for physical shopping trips. The third possibility is that there are only very limited effects in the number of physical shopping trips because each trip has multiple purposes. Thus even if some errands are substituted by online purchases, other physical visits to a store may be necessary (Mokhtarian 2004). In Sweden, most goods purchased online are picked-up at ollecting points that are often located in the same building as a grocery store (Bring 2013). In the Swedish case, online shopping thus generates pick-up trips to these locations and this influences travel behaviour. 
Focusing on the total number of passenger trips, one must recognize that online shopping could very well result in no reduction at all or even an increase in trips in line with findings on the effects of telecommuting. In the mid-seventies, telecommuting was predicted to be substitute for traditional forms of transportation for commuting (Niles and Gray 1975). However, the empirical results from, e.g., Niles (2001), de Graaff (2004), and Choo and Mokhtarain (2007), among many other authors, suggest that telecommunications and travel are complementary and even increase total travel. Gould and Golob (1997) argue that, analogous to the finding that saved travel for work is converted into new trips, saved shopping travel might be converted into other types of travel. Thus, the combination of substitution and complementary effects on travel lead to a very complicated picture of the overall effect of online shopping. Even if there is a substitution effect in the number of shopping trips, there might be a rebound effect in other trips. This increase in other types of trips might, of course, occur even if the number of physical shopping trips is unaffected or increases.

A net mobility reduction is not necessarily beneficial for sustainability because this reduction depends on whether shopping trips are made on foot, by bicycle, by public transport, or by car. Even if shopping by car generally is less sustainable than home delivery by delivery vans, shopping trips made by foot, bicycle, and public transport are still more sustainable. Another effect on mobility might be the effect on travel distance, i.e., an increased use of online shopping might result in purchases made further away or closer to home Therefore, it is necessary to include travel frequency, travel distance, and transportation mode in order to fully analyse the effect on travel behaviour. The travel distance combined with an analysis of the transportation mode must be considered as essential for analysing the effects related to sustainability in the transport system. These effects have, however, mostly been ignored in the research field.

There is a growing body of research indicating that online shopping acts as a substitute for personal shopping travel, e.g., Dixon and Marston (2002), Fischter (2002), Corpuz and Peachman (2003), Weltevreden and Van Rietbergen (2007). There are also empirical results indicating that online shopping has a limited or even no impact on the number of trips and total distance travelled for shopping, e.g., Golob and Regan (2001), Sim and Koi (2002), Keskinen et al. (2002), Visser and Lanzendorf (2004), Weltevreden (2007), and Rotem-Mindali and Weltevreden (2013). Focusing on online searching, there are studies claiming that there is a positive effect between online shopping and mobility behaviour resulting in additional travelling due to the online options and accessibility, e.g., Farag et al. (2006) and Farag et al. (2007). Finally, there are studies reporting empirical evidence for both substitution and complementarity behaviour within different groups in the sample population. This is shown, for instance, in Tonn and Hemrick (2004) where the use of e-mail and/or the Internet resulted in some respondents substituting one or more trips to a bookstore but some making more trips to a bookstore.

There are a few studies discussing the effect of increased shopping online in relation to total travel. The study of Ferrel (2005) indicates that there is no reduction in travel as the share of shopping from home increases. Casas et al (2001) show that Internet shoppers make more physical shopping trips than non-Internet uses do, but they found no significant difference between Internet shoppers and non-Internet shoppers in the share of physical shopping trips out of all personal trips. According to Rotem-Mindall and Weltevreden (2013), this indicates that mobile persons tend to shop more online and that online shoppers have a greater affinity for consumerism.

As mentioned earlier, in order to discuss the sustainability potential related to $\mathrm{CO} 2$ emissions of increased online shopping there is a need to analyse the effects on travel distances in addition to the total number of trips. There is, however, only a limited number of studies taking the effects on travel distances for shopping into account, e.g., Fogarty (2003), Cairns et al (2004) and Geraghty (2004), but even these have focused on distances saved only for shopping. There are virtually no empirical studies that include the effects of shopping trips as well as all other trips carried out in terms of trip length, frequency, and modal choice based on an entire population.

In this paper, we provide results on travel behaviour for physical shopping trips (for groceries, other purchases, and the pick-up of goods purchased online) by frequent and regular online shoppers in Sweden and compare these with infrequent online shoppers. The analysis of the total number and length of shopping trips is based on a nationwide representative sample of the Swedish population. The results for travel behaviour give an indication as to whether frequent online shoppers differ in travel behaviour related to shopping trips compared to those who shop less frequently online or not at all. In order to analyse whether the same patterns are repeated for trips for other purposes, the analysis is also carried out for total trips made. 


\section{Material and Method}

\subsection{Web-based survey}

The methods for analysing the effect on mobility due to online shopping have varied significantly. Some studies have used surveys including self-reported data on travel behaviour before and after the use of the Internet. Other studies have used cross-sectional data analysing differences in travel behaviour between various groups by taking individual characteristics into account. There are pros and cons with both methods, and these are discussed, for example, in Rotem-Mindall and Weltevreden (2013).

In this study, a cross-sectional dataset was used to investigate the mobility behaviour of groups with different online shopping behaviours. In a web-based survey, the respondents were asked about their offline and online shopping behaviour as well as their travel behaviour. The study was performed as a web-based survey distributed to a representative panel of the Swedish population aged 18 and over using NOVUS, a web survey agency. The main part of the data collection was carried out in October 2011 and was completed by an additional data collection in October 2012 to ensure the representativeness of the sample. A total of 4,977 potential respondents received an invitation by email to participate in the research and to fill in an online questionnaire in 2011, and a total of 2673 invitations were sent out in 2012. Among the potential respondents, the survey in $2011(\mathrm{n}=3086$ respondents) showed a response rate of $62 \%$ and the 2012 survey ( $n=1390$ respondents) had a response rate of $52 \%$. The data were pooled after an analysis of national statistics showed that conditions in Sweden, such as income, gross domestic product, employment rate, and travel behaviour, did not change considerably between 2011 and 2012.

Post-stratification weights for age group and sex were applied to the pooled data separated by place of residence. Age categories were the same categories used by the Swedish Trade Federation in their follow-ups of online shopping habits, and place of residence was defined according to H-regions, which are homogeneous regions defined as distinct geographical areas in Sweden based on population density (SCB 2003).

\subsection{Data collection and questionnaire}

The questionnaire included background data, a travel diary, and questions on general shopping habits and attitudes. The questionnaire began with a individual one-day travel diary. The questionnaire was distributed over the week so that data could be collected for weekdays as well as for weekends. In the survey, a trip was defined as a movement from one place to another in order to run an errand. This is the same definition used in the Swedish national travel survey. Following this definition, a change in transport mode is not considered as a separate trip. For each trip, the respondent was asked to state the main mode of transport. All trips were included in the survey regardless of which means of transport mode the respondents used during the day. The design of the survey and the definitions used enable comparison with results from the national travel survey.

The respondents were also asked to answer questions regarding their shopping habits (online and offline) and to grade various delivery systems with respect to how satisfactorily they were perceived. The questions regarding online shopping behaviour were divided into questions on shopping for groceries and on shopping for other purchases (such as clothes, shoes, consumer electronics, furniture, tickets, music, and travel). In this study, online shopping is thus defined in its broad sense and includes all purchases that otherwise (without the Internet) would have normally required physical movement. Thus, this study focuses on physical mobility and does not include searching for information on the Internet or the amount of purchases made on the Internet.

At the end of the questionnaire, the respondents were asked to answer background questions regarding gender, income, family type, possession of a driver's license, access to a car, which municipality they lived in, and the location of their residence in the municipality.

\subsection{Classification of online shoppers}

The respondents were classified into three different groups of online shoppers based on their stated online shopping habits for groceries and other purchases.

- Frequent online shoppers: shop online (for groceries or other purchases) at least once a week

- Regular online shoppers: shop online (for groceries or other purchases) about once a month

- Not or non-regular online shoppers: shop online (for groceries or other purchases) once every six months or less. 


\section{Results}

\subsection{Statistics}

Table 1 shows the demographic and background statistics of the survey respondents divided according to their online shopping habits. In the dataset $9 \%$ of the respondents shop online frequently, $34 \%$ do so regularly, and $57 \%$ do so seldom or never. The distribution of observations corresponds to statistics presented by the Swedish Retail Institute (2013).

The survey results show that there are some differences among individuals who shop online frequently and regularly compared to those who do not regularly shop online in terms of gender, age, family type, place of residence in the urban area, and region of residence. There is a larger share of men (statistically significant at the 5\% level) among those who shop online frequently, and among those who rarely or never shop online there is a significantly larger share of women. The group that rarely or never shops online also has a slightly older age profile. We also find more pensioners and fewer families with children under 10 years of age in the category of people who rarely or never shop online.

The results further indicate that in Stockholm and in the central parts of larger cities or urban areas there is a larger share of frequent online shoppers than those who do not regularly shop online. Moreover, frequent online shoppers are significantly less likely to have a driver's license or always have access to a car. However, the results also indicate that the number of observations, especially for frequent online shoppers, is low when analysing some subcategories, e.g. geographical distribution, affect the statistical significance.

Looking at the characteristics of frequent online shoppers in Table 1, there are factors speaking both for and against this group having different travel behaviour than the other two groups. Based on previous work such as that of Frändberg and Vilhelmson (2011) that analysed mobility trends in Sweden, one might argue that frequent online shoppers make more trips and more trips by car because there is a higher share of men and a higher share of people aged 36-55 in this group. On the other hand, one might also argue that frequent online shoppers make fewer trips and fewer trips by car because there is a larger share of individuals living centrally with a lower share of driver's licenses and access to a car and living in families without children. Thus, there is no clear indication that a difference in travel behaviour between the studied consumer groups depends on differences in the background characteristics.

Table 1. Background data for the different categories of online shoppers

\begin{tabular}{|c|c|c|c|c|}
\hline Typology & Frequent & Regular & Not or non-regular & All \\
\hline Number of respondents & 321 & 1,400 & 2,427 & 4,148 \\
\hline Share of total sample & $9 \%$ & $34 \%$ & $57 \%$ & $100 \%$ \\
\hline \multicolumn{5}{|l|}{ Gender } \\
\hline Female & $44 \%$ & $48 \%$ & $52 \%$ & $50 \%$ \\
\hline Male & $56 \%$ & $52 \%$ & $48 \%$ & $50 \%$ \\
\hline \multicolumn{5}{|l|}{ Age } \\
\hline $15-22$ & $13 \%$ & $15 \%$ & $13 \%$ & $13 \%$ \\
\hline $23-35$ & $26 \%$ & $27 \%$ & $18 \%$ & $22 \%$ \\
\hline $36-55$ & $38 \%$ & $35 \%$ & $32 \%$ & $34 \%$ \\
\hline $56-80$ & $24 \%$ & $23 \%$ & $37 \%$ & $31 \%$ \\
\hline \multicolumn{5}{|l|}{ Family type } \\
\hline Family with children under 10 years of age & $22 \%$ & $24 \%$ & $18 \%$ & $21 \%$ \\
\hline Family with teenage children & $15 \%$ & $16 \%$ & $14 \%$ & $15 \%$ \\
\hline Adults without children & $50 \%$ & $45 \%$ & $45 \%$ & $46 \%$ \\
\hline (At least one) pensioner & $13 \%$ & $15 \%$ & $22 \%$ & $19 \%$ \\
\hline \multicolumn{5}{|l|}{ Place of residence } \\
\hline Centrally in main town & $44 \%$ & $41 \%$ & $34 \%$ & $37 \%$ \\
\hline Suburbs of main town & $35 \%$ & $35 \%$ & $37 \%$ & $36 \%$ \\
\hline In village & $15 \%$ & $12 \%$ & $15 \%$ & $14 \%$ \\
\hline In the countryside & $6 \%$ & $12 \%$ & $14 \%$ & $13 \%$ \\
\hline
\end{tabular}


Table 1. (continued) Background data for the different categories of online shoppers

\begin{tabular}{lcccc}
\hline Typology & Frequent & Regular & Not or non-regular & All \\
\hline Homogeneous regions & & & & \\
Stockholm & $31 \%$ & $23 \%$ & $19 \%$ & $22 \%$ \\
Gothenburg & $12 \%$ & $10 \%$ & $9 \%$ & $10 \%$ \\
Malmö & $5 \%$ & $6 \%$ & $7 \%$ & $7 \%$ \\
Dense areas & $36 \%$ & $36 \%$ & $38 \%$ & $37 \%$ \\
Semi-dense areas & $11 \%$ & $15 \%$ & $17 \%$ & $16 \%$ \\
Semi-rural areas & $4 \%$ & $5 \%$ & $5 \%$ & $5 \%$ \\
Rural areas & $2 \%$ & $4 \%$ & $4 \%$ & $4 \%$ \\
Driver's license & & & & \\
No & $17 \%$ & $13 \%$ & $12 \%$ & $13 \%$ \\
Yes & $83 \%$ & $87 \%$ & $88 \%$ & $87 \%$ \\
Access to a car & & & & \\
Always & & & $59 \%$ & $56 \%$ \\
Most of the time & $48 \%$ & $54 \%$ & $19 \%$ & $20 \%$ \\
Sometimes & $24 \%$ & $21 \%$ & $8 \%$ & $9 \%$ \\
Rarely & $10 \%$ & $10 \%$ & $7 \%$ & $8 \%$ \\
Never & $9 \%$ & $7 \%$ & $6 \%$ & $7 \%$ \\
\hline
\end{tabular}

In Table 2 the total number of trips (unweighted) is presented for the defined groups of online shopping habits and by car and other transport modes. The data are further separated into various errands and trip purposes. The errands considered are shopping trips (shopping trips for groceries, shopping trips for purchases other than groceries, and pick-up of goods purchased on the Internet) and other purposes. In total, the dataset contained information on almost 15,600 trips. However, as shown in Table 2, the number of trips for frequent online shoppers when divided into various types of trips is limited and will affect the statistical analysis of the data. The number of observations when studying all modes exceeds the sum of trips by car and other modes than car because these figures include those respondents who did not indicate the type of transport mode in their questionnaire.

Table 2. Total number of trips in the dataset (unweighted) for online shopping habits and transport mode

\begin{tabular}{|c|c|c|c|c|c|c|c|c|c|}
\hline & \multicolumn{9}{|c|}{ Number of trips in the dataset ... } \\
\hline & \multicolumn{3}{|c|}{$\begin{array}{l}\text {...by car for those who shop } \\
\text { online... }\end{array}$} & \multicolumn{3}{|c|}{$\begin{array}{l}\text {...by another mode than car } \\
\text { for those who shop online... }\end{array}$} & \multicolumn{3}{|c|}{$\begin{array}{l}\text {...by all modes for those who } \\
\text { shop online... }\end{array}$} \\
\hline & 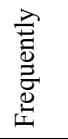 & 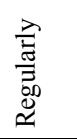 & $\begin{array}{l}\dot{0} \\
\dot{0} \\
\stackrel{0}{0} \\
\text { z } \\
\end{array}$ & 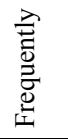 & 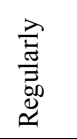 & $\begin{array}{l}\dot{0} \\
\dot{0} \\
\bar{d} \\
\overline{0} \\
z\end{array}$ & 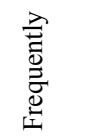 & 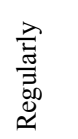 & $\begin{array}{l}\ddot{0} \\
\dot{0} \\
\dot{0} \\
\dot{0} \\
\bar{d}\end{array}$ \\
\hline Shopping trips (total) & 153 & 588 & 856 & 96 & 216 & 264 & 274 & 881 & 1234 \\
\hline Groceries & 86 & 353 & 516 & 41 & 113 & 125 & 152 & 542 & 752 \\
\hline Other purchases & 56 & 209 & 315 & 33 & 80 & 121 & 89 & 290 & 439 \\
\hline $\begin{array}{l}\text { Collecting online } \\
\text { purchases }\end{array}$ & 11 & 26 & 25 & 22 & 23 & 18 & 33 & 49 & 43 \\
\hline Other purposes & 726 & 3,018 & 4,101 & 639 & 2,220 & 2,514 & 1,355 & 5,240 & 6,606 \\
\hline Total trips & 879 & 3,606 & 4,957 & 735 & 2,436 & 2,778 & 1,629 & 6,121 & 7,840 \\
\hline
\end{tabular}

\subsection{Travel for shopping}

The travel behaviour for the different groups of online shopping habits was analysed by taking all shopping trips and errands into consideration and then separating for trips made by car and other transport modes. The results are presented both by daily distances and number of trips per day. Differences between shopping groups were tested using Tamhane's test for multiple datasets assuming different variances. 


\section{Number of shopping trips per person per day}

The number of shopping trips per person per day is presented in Table 3. The results do not indicate any statistically significant differences between the studied shopping groups. This result can be interpreted to mean that there are no major differences in number of visits to the shops whether one shops online or not. There is a tendency for frequent online shoppers to use other travel modes than a car when collecting goods purchased online, but this difference is not significant. Not surprisingly, frequent online shoppers make significantly more trips than the other groups for the main purpose of picking up goods purchased online.

Table 3. Number of shopping trips per person per day for online shopping habits and transport mode

\begin{tabular}{|c|c|c|c|c|c|c|c|c|c|}
\hline & \multicolumn{3}{|c|}{$\begin{array}{l}\text { Trips by all modes for those } \\
\text { who shop online... }\end{array}$} & \multicolumn{3}{|c|}{$\begin{array}{l}\text { Trips by car for those who } \\
\text { shop online... }\end{array}$} & \multicolumn{3}{|c|}{$\begin{array}{l}\text { Trips by another mode than car } \\
\text { for those who shop online... }\end{array}$} \\
\hline & 总 & $\begin{array}{l}\overrightarrow{\vec{E}} \\
\frac{\vec{E}}{\vec{E}} \\
\stackrel{0}{\alpha}\end{array}$ & $\begin{array}{l}\dot{\overline{0}} \\
\overline{0} \\
\overline{0} \\
\overline{0} \\
\overline{0} \\
\overline{0}\end{array}$ & 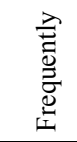 & 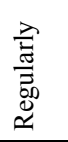 & 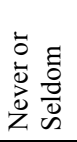 & 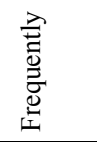 & 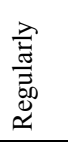 & 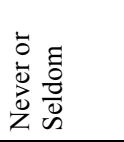 \\
\hline Shopping trips (total) & 0.63 & 0.60 & 0.62 & 0.40 & 0.39 & 0.40 & 0.18 & 0.14 & 0.13 \\
\hline \multicolumn{10}{|l|}{ By shopping errand: } \\
\hline Groceries & 0.35 & 0.37 & 0.39 & 0.21 & 0.24 & 0.26 & 0.08 & 0.08 & 0.07 \\
\hline Other purchases & 0.22 & 0.19 & 0.20 & 0.15 & 0.14 & 0.14 & 0.06 & 0.05 & 0.06 \\
\hline $\begin{array}{l}\text { Collecting online } \\
\text { purchases }\end{array}$ & $0.07 *$ & 0.03 & 0.02 & $0.03 *$ & 0.01 & 0.01 & $0.04 *$ & 0.01 & 0.01 \\
\hline
\end{tabular}

* Significant difference between frequent online shoppers and the other two groups at the 5\% level.

\section{Distances travelled per day for shopping trips}

Based on the travel diaries, the total distance travelled per person per day was calculated and analysed (Table 4). For the total number of shopping trips and regarding all transport modes, there is a significant difference between frequent and regular online shoppers and those who never or seldom shop online. Separating this result for transport mode and shopping errand, the result indicates that this difference stems from longer travel distances by car (almost twice as long as frequent online shoppers) for those who never or seldom shop online and mainly for other purchases than groceries. The travel distance by other transport modes than a car for shopping trips is the same. Regarding trips for pick-up of goods purchased online, there are longer trips made by car than by other transport modes.

Table 4. Travel distance for shopping trips in kilometre per person per day for online shopping habits and transport mode

\begin{tabular}{|c|c|c|c|c|c|c|c|c|c|}
\hline & \multicolumn{3}{|c|}{$\begin{array}{l}\text { Trips by all modes for those } \\
\text { who shop online... }\end{array}$} & \multicolumn{3}{|c|}{$\begin{array}{l}\text { Trips by car for those who } \\
\text { shop online... }\end{array}$} & \multicolumn{3}{|c|}{$\begin{array}{l}\text { Trips by another mode than } \\
\text { car for those who shop } \\
\text { online... }\end{array}$} \\
\hline & 忞 & 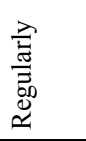 & 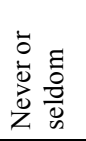 & 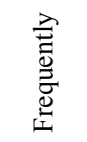 & 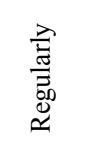 & 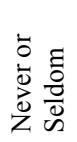 & 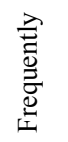 & 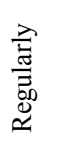 & $\begin{array}{l}\dot{0} \\
\dot{0} \\
\dot{0} \\
\dot{0} \\
\ddot{D} \\
\tilde{D}\end{array}$ \\
\hline Shopping trips (total) & $4.9^{\mathrm{F}, \mathrm{N}}$ & $4.6^{\mathrm{R}, \mathrm{N}}$ & 8.4 & $3.0^{\mathrm{F}, \mathrm{N}}$ & $2.9^{\mathrm{R}, \mathrm{N}}$ & 5.5 & 0.4 & 0.4 & 0.5 \\
\hline \multicolumn{10}{|l|}{ By shopping errand: } \\
\hline Groceries & 2.4 & $2.0^{\mathrm{R}, \mathrm{N}}$ & 3.4 & 1.4 & $1.3^{\mathrm{R}, \mathrm{N}}$ & 2.2 & 0.2 & 0.2 & 0.2 \\
\hline Other purchases & $1.7^{\mathrm{F}, \mathrm{N}}$ & $2.2^{\mathrm{R}, \mathrm{N}}$ & 4.5 & $1.2^{\mathrm{F}, \mathrm{N}}$ & $1.5^{\mathrm{R}, \mathrm{N}}$ & 3.0 & 0.2 & 0.2 & 0.2 \\
\hline Collecting online purchases & 0.5 & 0.1 & 0.1 & 0.3 & 0.0 & 0.1 & 0.0 & 0.0 & 0.1 \\
\hline
\end{tabular}

F-Frequent, R-Regular, N-Never or seldom. Significant difference between groups at the 5\% level.

\subsection{Total travel including other purposes than shopping}

The analysis was also carried out for all trips made in order to study whether similar results regarding shopping trips are also seen for other trip purposes in terms of the number of trips, trip distances, and transport modes. The results are presented for total travel as well as for shopping trips and for other purposes and errands separately. 


\section{Total number of trips}

The results for all transport modes and total travel suggest that the frequency of online purchases is positively correlated with the number of trips made per person per day (Table 5). People who frequently and regularly shop online make significantly more trips per person per day when all transport modes are studied in terms of the number of trips made for other purposes than shopping. This pattern is also seen when analysing total travel by other modes than a car. Frequent and regular online shoppers thus make significantly more trips by bicycle, by foot, and by public transport than those who never or seldom shop online. The number of trips made by car is almost the same regardless of online shopping habits.

Table 5. Total number of trips per person per day for online shopping habits and transport mode

\begin{tabular}{|c|c|c|c|c|c|c|c|c|c|}
\hline & \multicolumn{3}{|c|}{$\begin{array}{c}\text { Trips by all modes for those who } \\
\text { shop online... }\end{array}$} & \multicolumn{3}{|c|}{$\begin{array}{l}\text { Trips by car for those who } \\
\text { shop online... }\end{array}$} & \multicolumn{3}{|c|}{$\begin{array}{c}\text { Trips by another mode than } \\
\text { car for those who shop } \\
\text { online... }\end{array}$} \\
\hline & 营 & 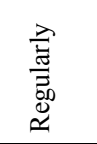 & $\begin{array}{l}\dot{0} \\
\dot{0} \\
\dot{0} \\
\overline{0} \\
\overline{0}\end{array}$ & 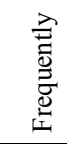 & $\frac{\lambda}{\vec{\Xi}}$ & 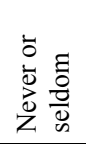 & 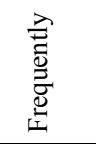 & 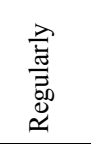 & 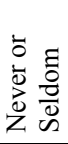 \\
\hline Total travel & $2.63^{\mathrm{F}, \mathrm{N}}$ & $2.60^{\mathrm{R}, \mathrm{N}}$ & 2.47 & 1.48 & 1.51 & 1.50 & $1.12^{\mathrm{F}, \mathrm{N}}$ & $1.05^{\mathrm{R}, \mathrm{N}}$ & 0.93 \\
\hline \multicolumn{10}{|l|}{ By trip purpose } \\
\hline Shopping (total) & 0.63 & 0.60 & 0.62 & 0.40 & 0.39 & 0.40 & 0.18 & 0.14 & 0.13 \\
\hline Other & $1.98^{\mathrm{F}, \mathrm{N}}$ & $1.97^{\mathrm{R}, \mathrm{N}}$ & 1.83 & 1.07 & 1.09 & 1.07 & $0.88^{\mathrm{F}, \mathrm{N}}$ & $0.83^{R, N}$ & 0.71 \\
\hline
\end{tabular}

F-Frequent, R-Regular, N-Never or seldom. Significant difference between groups at the $5 \%$ level.

\section{Total travel distance}

The results for total travel by all modes mirror the results for shopping trips in that people who shop online frequently and regularly travel shorter distances than those who never or seldom shop online (Table 6). The difference in distance between frequent online shoppers and those who never or seldom shop online is significant for trips made by car. The pattern is the same when looking at other trip purposes than shopping for all transport modes and trips made by car, but for other modes than a car the travel distance is longer for frequent online shoppers than the other categories.

Table 6. Travel distance in kilometre per person per day for online shopping habits and transport mode

\begin{tabular}{|c|c|c|c|c|c|c|c|c|c|}
\hline & \multicolumn{3}{|c|}{$\begin{array}{l}\text { Trips by all modes for those } \\
\text { who shop online... }\end{array}$} & \multicolumn{3}{|c|}{$\begin{array}{l}\text { Trips by car for those who } \\
\text { shop online... }\end{array}$} & \multicolumn{3}{|c|}{$\begin{array}{c}\text { Trips by another mode than } \\
\text { car for those who shop } \\
\text { online... }\end{array}$} \\
\hline & 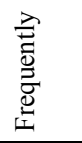 & 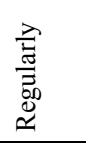 & 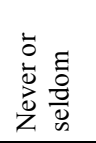 & 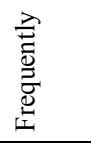 & 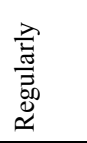 & 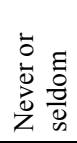 & 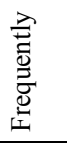 & 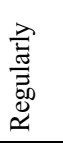 & $\begin{array}{l}\dot{0} \\
\dot{0} \\
\dot{0} \\
\dot{0} \\
\dot{0} \\
\dot{0}\end{array}$ \\
\hline Total travel & 52.7 & 57.3 & 62.7 & $24.1^{\mathrm{F}, \mathrm{N}}$ & 28.5 & 33.1 & 27.0 & 26.6 & 26.9 \\
\hline \multicolumn{10}{|l|}{ By trip purpose } \\
\hline Shopping (total) & $4.9^{\mathrm{F}, \mathrm{N}}$ & $4.6^{\mathrm{R}, \mathrm{N}}$ & 8.4 & $3.0^{\mathrm{F}, \mathrm{N}}$ & $2.9^{\mathrm{R}, \mathrm{N}}$ & 5.5 & 0.4 & 0.4 & 0.5 \\
\hline Other & 47.0 & 52.0 & 53.0 & 20.9 & 25.3 & 27.1 & 17.1 & 14.4 & 14.2 \\
\hline
\end{tabular}

F-Frequent, R-Regular, N-Never or seldom. Significant difference between groups at the $5 \%$ level.

\section{Conclusions}

The continuing growth of online shopping has the potential to lead to changes in mobility patterns. In theory, physical shopping trips could be more or less replaced by goods delivery systems and thus lead to a considerable reduction in travel mileage. The majority of online shoppers are younger, and as this generation grows older they will bring these habits with them. Furthermore, frequent online shoppers had less access to a car and they also were more likely not to have a driver's license, both of which are factors that have proven to be important for reductions in vehicle mileage. 
In order to discuss the sustainability implications of online shopping, it is important to analyse mobility in terms of travel frequency, travel length, and modal split. When analysing shopping trips, the result of this study indicates no major differences between the groups of online shopping habits in terms of the total number of physical shopping trips made and irrespective of the type of shopping trip being studied. There is a tendency, however, that frequent online shoppers make more trips by other travel modes than car, including public transport, bicycle, or walking, when picking up goods purchased online.

As opposed to many other studies, the travel distance is also included in the analysis presented here. Our results indicate that frequent online shoppers tend to travel significantly shorter distances for shopping per day by car (almost half the distance of those who never or seldom shop online), but the travel distance by other modes than a car is almost the same as the other customer groups.

To broaden the picture, other types of trips than shopping were also studied. Here the travel pattern is somewhat different. Our results indicate that the number of trips for purposes other than shopping is significantly higher for frequent and regular online shoppers compared to those who never or seldom shop online. The number of car trips is the same irrespective of the category being studied, and it is the number of trips with other transport modes than a car that differ between the studied categories of shopping habits.

One could argue that when looking at factors related to sustainability the pattern is strengthened when considering the travel distance. If looking at car travel, those with frequent online shopping habits use the car as often as others but for shorter total distances. When it comes to travelling by other modes than car, those with frequent online shopping habits make more trips by bicycle, walking, and public transport than those with less frequent online shopping habits.

The differences in travel behaviour between consumer groups identified here might result from differences between individual characteristics and their potential for various travel behaviours. Among frequent online shoppers, there is a larger share of people living in central areas, with less access to a car, and who are younger than average. However, when analysing subsamples of the dataset (not presented in this article) with, for example, similar distances to various locations and public transport, there is still a persistent trend of differences between customer groups depending on online shopping behaviour though insignificant.

When looking at all shopping trips and all transport modes together, there are only small differences between the categories in the number of physical shopping trips made. This indicates that there are no major differences in the number of visits to the shops and that online shopping does not reduce the demand for travel to any significant degree. Instead, our results indicate a complementarity effect for both shopping trips and other errands in that the time saved by purchasing items online is used for making additional physical shopping trips as well as trips for other purposes. This is also in line with the result from other empirical studies, e.g. Casas el al (2001) and Cao et al (2010), that have indicated generally high levels of mobility and consumerism among individuals exhibiting frequent online shopping behaviour.

When looking at the individual characteristics and mobility patterns of people frequently and regularly shopping online, the results of this study indicate a potential for reducing car mileage. There is, however, nothing to suggest that this potential can be realized solely through the growth of online shopping in the population, and online shoppers currently show few significant differences in travel behaviour in terms of the total number of trips and the total daily distances travelled. There is a strong concern that travel savings for one purpose, in this case shopping, are used for other purposes instead.

Although we doubt that online commerce can act as a stand-alone measure for vehicle mileage reduction, online shopping might increase the use of more sustainable modes for shopping trips as well as other trip purposes - even on a short-term basis. Online shopping could, therefore, act as a facilitator for a less car-dependent lifestyle. The results presented here are based on current societal structures, land uses, and travel patterns. Even now, those frequently using online shopping are not a homogenous group and this will become even more obvious when online shopping becomes more common and used, more or less, by everyone. This stresses the importance of supporting more sustainable transport modes through infrastructure as well as the planning of shopping locations. We also argue that research and analyses should focus on how the sustainability potential of online shopping can be supported. For instance, because frequent online shoppers use other modes than a car for shopping for groceries, this indicates that urban planning should focus on ensuring safe and accessible routes for walking, biking, and public transport for these types of purchases.

The dataset has also revealed interesting information with implications for the retail sector in that frequent online shoppers have almost the same number of physical visits to shops as those not shopping online. The fear of having less people in the stores due to the growth of e-commerce seems to be ill 
founded. However, in this study we have not been investigating whether the amount of purchase in the shops differs between the consumer groups. Thus it could very well be the case that frequent online shoppers go to the physical store only for the purpose of gathering information. On the other hand, and as expected, the data show that frequent online shoppers make more trips than the other groups with the purpose of picking up goods purchased online.

\section{References}

1. Bring (2013) The E-commerce Report 2013

2. Casas, J., Zmud, J. and Bricka, S. (2001). Impact of shopping via internet on travel for shopping purposes. In: Proceedings of the 80th Annual Meeting of the Transportation Research Board, January 7-11, Washington DC.

3. Choo, S. and Mokhtarian, P. L. (2007) Telecommunications and travel demand and supply: Aggregate structural equation models for the US. Transportation Research Part A, 41 (1) 4-18.

4. Corpuz, G. and Peachman, J. (2003) Measuring the impacts of Internet usage on travel behaviour in the Sidney Household Travel Survey. In: Proceedings of the 26th Australian Transport Research Forum Conference. Wellington, New Zealand.

5. Crocco, F., Eboli, L., and Mazzulla, G. (2013). Individual attitudes and shopping mode. Characteristics affecting the use of e-shopping and related travel, Transport and Telecommunication, 14 (1) $45-56$.

6. Dixon, T. and Marston, A.D. (2002) UK retail real estate and the effects of online shopping. Journal of Urban Technology, 9 ( 3) 19-47.

7. Graaff, T. de (2004) On the substitution and complimentarity between telework and travel: A review and application. Faculty of Economics, Business Administration and Econometrics, Free University of Amsterdam, Amsterdam. Research Memoranda 0016.

8. Farag, S., Krizek, K. J. and Dijst, M. (2006). E-Shopping and its Relationship with In-store Shopping: Empirical Evidence from the Netherlands and the USA. Transport Reviews. 26 (1) 43-61.

9. Farag, S., Schwanen,T. and Dijst, M., Faber, J. (2007) Shopping on line and/or in-store? A structural equation model of the relationships between e-shopping and in- store shopping. Transportation Research Part A, 41 (2) 125-141.

10. Ferrell, C. E. (2005). Home-based Teleshopping and Shopping Travel: Where do we find the Time? Transportation Research Record, 1926, 211-223.

11. Fichter, F. (2002) E-commerce: sorting out the environmental consequences. Journal of Industrial Ecology, 6 (2) 25-41.

12. Fredriksson, T. (2013) E-commerce and development: Key trends and issues. United Nations Conference on Trade and Development. Presentation at Workshop on E-Commerce, Development and SMEs, 8-9 April 2013, World Trade Organisation, Geneva, Switzerland.

13. Frändberg, L. and Vilhelmson, B. (2011) More or less travel: personal mobility trends in the Swedish population. Journal of Transport Geography, 19 (6) 1235-1244.

14. Golob, T.F. and Regan, A.C. (2001) Impacts of information technology on personal travel and commercial vehicle operations: research challenges and opportunities. Transportation Research Part C, 9 (2) 87-121.

15. Gould J. and Golob T F (1997) Shopping without travel or travel without shopping? An investigation of electronic home shopping. Transport Reviews, 17, 355-376

16. Keskinen, A., Delache, X., Cruddas, J., Lindjord, J.E. and Iglesias, C. (2002) A Purchase and a Chain, Impacts of E-commerce on Transport and the Environment OECD, Paris

17. Mokhtarian, P.L. (1990) A typology of relationships between telecommunications and transportation. Transportation Research Part A, 24 (3) 231-242.

18. Mokhtarian, P.L. (2002) Telecommunication and travel: the case for complementarity. Journal of Industrial Ecology, 6 (2) (2002), pp. 43-57.

19. Mokhtarian, P.L. (2004) A conceptual analysis of the transportation impacts of B2C e-commerce, Transportation, 31 257-284.

20. Niles J. S. and Gray P. (1975). Telecommuting - a possible transport substitute. Logistics Transport Review, 11 185-191. 
21. Niles, J. S. (2001) Technology and Transportation: The Dynamic Relationship. Discovery Institute Inquiry, X (II) September.

22. Rotem-Mindali,O. and Weltevreden J.W.J. (2013) Transport effects of e-commerce: what can be learned after years of research? Transportation, 40 867-885.

23. Salomon, I. (1986) Telecommunications and travel relationships: a review. Transportation Research, 20 (23) 223-238.

24. SCB (2003). Area Range of H Regions. http://www.scb.se/Grupp/Hitta_statistik/Regional\%20statistik/Kartor/_Dokument/Hregion_farg_karta.pdf

25. Sim, L.L. and Koi S.M. (2002) Singapore's Internet shoppers and their impact on traditional shopping patterns. Journal of Retailing and Consumer Services, 9 (2) 115-124.

26. Swedish Trade Federation (2010) Så handlar vi på nätet..

27. Swedish Institute of Retail (2013) E-barometern Årsrapport 2012.

28. Tonn, B.E. and Hemrick A. (2004) Impacts of the use of e-mail and the Internet on personal tripmaking behaviour. Social Science Computer Review, 22 (2) 270-280.

29. Trivector (2011) Hållbara besöksresor till köpcentra - förslag på strategier i Skåne. (Sustainable visits to shopping malls - suggested strategies in Skåne) Report 2011:111.

30. Weltevreden, J.W.J. (2007) Substitution or complimentary? How the Internet changes city centre shopping, Journal of Retailing and Consumer Services, 14 192-207 .

31. Weltevreden, J.W.J. and van Rietbergen, T. (2007). E-shopping versus city centre shopping: the role of perceived city centre attractiveness. Journal of Economic \& Social Geography, 98 (1) 68-85.

32. Weltevreden J.W.J. and Rotem-Mindali,O. (2009) Mobility effects of b2c and c2c e-commerce in the Netherlands: a quantitative assessment Journal of Transport Geography, 17(2) 83-92.

33. Visser E.J. and Lanzendorf, M. (2004) Mobility and accessibility effects of B2C E-commerces: a literature review, Tijdschrift voor Economische en Sociale Geografie, 95(2) 189-205.

34. Cao, X., Douma,, F. and Cleaveland, F. (2010) Influence of E-Shopping on Shopping Travel: Evidence from the Twin Cities. Transportation Research Record, 2135 160-169. 